\title{
Bilingual Children: The Benefits and Challenges
}

\author{
Andarini Permata Cahyaningtyas \\ Prodi PGSD, FKIP, Universitas Islam Sultan Agung, Jln. Kaligawe Raya Km.4 Genuk - \\ Semarang \\ \{andarinipermata@unissula.ac.id\}
}

\begin{abstract}
Indonesia is a large country with different languages and cultures. That is why the obligation to master national language besides regional language and intercultural marriage are two of some reasons that Indonesian children have been being bilinguals since they were born. Therefore, this study aims to find the benefit to be bilinguals and what kind of challenges do they have to face. This is a library research that the data were collected by analysing journals and books. The result of this study showed that bilingual children experience some benefits compared to monolinguals, such as understanding two separate language systems and grammar principles, having better working memory and executive functioning, and mastering more receptive vocabulary. Meanwhile, the challenges they need to face are that they have to deal with code switching.
\end{abstract}

Keywords: language, bilingual, monolingual, children, code switching

\section{Introduction}

Indonesia is a culture-rich country that owns thousand traditions. Every tribe has its own local language, but it is not a challenge for Indonesian people to communicate with them from different areas because we have our national language, Indonesian. Actually, Allah has spoken in Quran 49:13 that He has created humankind from male and female, and made you peoples and tribes that you may know one another. This causes most of Indonesian have become bilinguals since they were babies.

To understand language acquisition, we should grasp several terms such as first and second language. First language is the language (or languages) acquired by children from parents in their first five years. This condition can be categorized as simultaneous bilingualism (when someone get two or more languages at once). Meanwhile, if children obtain their second language (or languages) after they settle the fundamental structure of his first language or after the age of five years, this circumscription will be included in consecutive bilingualism (when someone get the languages sequentially[1,2]. This means second language does not limited to the "second" language, but also it can be the third, fourth, etc.[3].

As we know, there are two theories connected to language acquisition, nativistic and behaviouristic[4]. Behaviourists believe that the biggest effect for children's language development is the environment. The more stimulus they get, the more responds they will give, and vice versa. Contrary, nativists state that human is born with Language Acquisition Device (LAD) that allow us to understand any languages in the world. Based on this theories, we can understand that mastering languages is a given for human because of our brain ability to conquer any language and possible to be more than a language, though the surrounding also has to be language-rich so children can learn languages unconsciously in their everyday life. 
There are also other reasons that kids can be bilinguals. In Indonesia, cross-culture marriage becomes a big rational for the escalation of the number of bilingual children. For example, if a Javanese woman marry Sundanese man, they are more likely to communicate in Indonesian. However, their children will have chance to learn three languages at once since they were born: Sundanese, Javanese, and Indonesian. Mastering local languages is important for a child to be able to converse with their family in their hometown, because there are many old people who cannot or at least are not fluent in Indonesian. Especially in Javanese, many grandparents who talk to their grandchildren with krama alus, the highest level in Javanese, that should be used by youngsters when they communicate with elderly. By talking in krama alus, they teach their grandchildren to learn how to choose vocabularies that are suitable to adjust to certain situation. Although, that does not mean that children will be totally understand adults who speak in different languages, at least they will be able to learn new things by conversing in some languages with different people.

Even so, there are people who believe that being a bilingual is harmful for children's language development. This fear causes many educational practitioners advice parents to simplify their kids' language environment when they show any difficulties in talking, and language specialists create manuals for parents to introduce language to their children young kids to minimalize their confusion. However, those believes are only based on fear and anecdotes5. Many researchers have conducted studies with bilingual kids as their subject to prove that bilingualism gives advantages for them. This paper will discuss what kind of positive things they will experienced and what challenges they have to face when they become bilinguals since they were babies. This can be a guidance for parents to help children to fulfil their language developmental tasks.

\section{Method}

This research was conducted by using library research method that included some phases: a) preparing tools; b) arranging a working bibliography; c) managing time; and d) reading and writing a research note[6]. The data sources were obtained from scientific literature such as books and journal articles that are relevant to the topic. The data were collected using checklist instrument to classify the material based on the research focus and scheme. Then, it was analysed using content analysis and double-checked to make sure and maintain its validity.

\section{Results and Discussions}

Generally, we can say that language development in bilinguals is just the same with monolinguals. Even, there are several benefits gained by bilinguals during their growth because bilingualism is one of children's experiences that can affect their cognitive function. However, being bilinguals makes them undergo some challenges while using and separating two language systems in one time. Here we will discuss about those in details. 


\subsection{The benefits to be bilinguals}

\section{a) In distinguishing sound}

Being a bilingual makes children capable to differ sounds in each language. That ability has become their precondition in acquiring the two language systems[7]. For example, babies who were born in cross-culture family that speak two languages will get used to hear their parents speak in two different languages. They can differ which sound they listen to and conclude what language their parents is using at that time. As we know, pronunciation in Indonesian and English is very different, e.g. in pronouncing 'c'. In Indonesian, 'c' is only pronounced as /c/ wherever the letter ' $c$ ' is in a word, like in the word 'cacar'. Therefore, in English ' $c$ ' is pronounced in several ways, such as $/ \mathrm{k} /$ in 'car' and $/ \mathrm{s} /$ in 'city'. By understanding more than a sound, bilingual children will be able to know what language is being spoken in every language processing situation. This ability is definitely not possessed by monolinguals that only acquire one language.

\section{b) In encoding, decoding, and choosing language}

Decoding is a process in comprehending the message, while encoding is vice versa, which is a process to code the message in language symbol. In these abilities, bilingual children are proven greater, and their ability in using grammar is better than monolinguals [8]. This because they get used to break the code in those two languages in a situation. Another reason is that they put more attentions to the input they acquire [9]. They will understand that different input means different respond, and sometimes it depends on who is talking, also when and where it happens. By mastering more than a language, they will have more options in maintaining communication and become more sensitive to the choice of language they use contextually.

For instance, in Central Java, children tend to communicate in Javanese when they are talking to family member and using Indonesian when they are communicating with other people, such as neighbours, friends from school, or teachers. As I mentioned before, in speaking Javanese, they will differentiate what words they should use, whether from ngoko, krama alus, or krama inggil, based on whom they need to talk to. Besides, bilinguals will be able to respond in one particular language although other people ask in various language[10]. For example, in family gathering, sometimes the family members are from different regions that speak in different dialect or language. When children understand the dialect or the language but find it difficult to respond in the same way, they will use Indonesian as they know that everybody will understand their answers, because sometimes they understand more vocabularies but they are not used to using it actively.

\section{c) In receptive vocabulary mastery}

Receptive vocabulary is all vocabularies that are understood by someone. If we count vocabularies in a language, monolinguals indeed master more vocabularies than bilinguals do. However, if we count all vocabularies bilinguals acquire from two languages, they beat monolinguals $[11,12]$. This because bilinguals learn more than a label for one thing, such as 'green' and 'hijau' when they refer to the fourth colour of the rainbow. By mastering at least two labels for each object, they automatically acquire more vocabularies than monolinguals that only understand a label for an object. 


\section{d) In cognitive skill}

Bilinguals demonstrate a better cognitive skill performance than monolinguals, expert says. They are good in focusing attention to information they are gathering, such as when they need to compare two things and find the differences[13]. In acquiring two languages, they are used to doing this kind of things, supposed to be able to understand the languages and give respond properly. Compare to monolinguals, bilingual children respond faster and show executive functioning better[14]. Executive functioning involves their flexibility, and their ability in paying attention, choosing an option, refraining their self, and moving. Specifically, cognitive control ability that bilinguals excel at are divided into two types: (a) attentional inhibition, that is the ability to ignore unimportant information that can disturb their attention while focusing in relevant information; and (b) attentional monitoring, which is the ability to follow and respond to the given task[15].

No matter what languages they acquire, bilinguals will experience this kind of advantages compare to monolinguals. This can be the basis for arguing against the opinion that being bilingual will hinder children's language development. Quite the opposite, they will perform better in cognitive and language skills as they grow and acquire more inputs from both languages. Their ability and flexibility in communicating with others will also develop more than monolinguals because they will get used to differentiating two language systems.

\subsection{The challenges to be bilinguals}

Beside those benefits, bilingual children still have to face some challenges regarding to the languages they have acquired. Especially when they do not balance the use of both languages, they will experience language dominance which one language is mastered faster than the other one[16]. This is in line with behaviouristic theory that believes that children's language development is influenced by their habit and surrounding. The more often a language is used, the more fluent they will be. For example, a child who is raised by a Sundanese father and Javanese mother but has been living in Bandung will have chance to grow by acquiring three languages: Sundanese, Javanese, and Indonesian. However, because the neighbourhood mostly speaks in Sundanese, he/she will experience Sundanese as her/his language dominance.

Furthermore, there is another challenge faced by bilingual when they combine two languages in an utterance. This is called code switching, a condition when people change their language completely before returning to the original language. This often occurs in bilingual people, such as immigrant, minority, and multilingual community[17,18]. When someone is conducting a code switching, they generally use a dominant language, then switch into another language form (it can be word, phrase, or sentence) then be back to the original. Based on the form, there are four types of code switching, namely inter-sentential switching, intra-sentential switching, tag switching, and establishing continuity with previous speaker [19]. Here are the explanation:

\section{a) Inter-sentential switching}

This switching type occurs outside the sentence, and it usually is another sentence said in another language. For instance, "Coba liat! Rainy outside." [20]. This switching happens when children from multilingual community are talking to each other. The speaker used 
Indonesian and English to describe the weather to her/his friends. Bilingual children use this type a lot when they are used to speaking in two language simultaneously.

\section{b) Intra-sentential switching}

In this type, the switching happens inside the sentence, when there is word(s) or phrase(s) that is included[21]. For example, intra-sentential switching that was said by Ternate kid that combined Indonesian and Melayu Ternate in his/her utterance. He/she said, "Di Santiong, dorang pe rumah bagus!"[22]. In Indonesian, dorang means they, and pe refers to ownership. So, that sentence means "In Santiong, their houses are great." People who has become bilingual since they were kids have bigger chance in doing intra sentential switching compare to them who learn the second language after 13th years of age. This also happens to them who are fluent in both languages[23]. For information, this type of switching is sometimes referred to as code mixing. This because code mixing is defined as a condition when someone uses two languages in the same utterance[24]. So, in this paper, code switching has included code mixing, while intra-sentential switching is a part of code switching.

\section{c) Tag switching}

Tag switching occurs when someone put interjections, fillers, tags, and idioms from another language in a sentence. This is the simplest form of code switching because it does not require a high level of grammar mastery[23]. As an example, when children greet their teacher by saying, "Good morning, Ibu Guru!"[20]. This might happen in multilingual school that use English and Indonesian as their daily languages. They simply put English words in an Indonesian sentence.

\section{d) Establishing continuity with previous speaker}

This switching type happens because of an adjustment conducted by someone when the interlocutors has spoken in other language first, but then he/she will be back to the original language. For instance, there is an Indonesian boy converses with an English girl using Indonesian. However, due to the limited Indonesian vocabulary, the English kid then switch to English to explain something. To adjust the situation, the Indonesian kid will respond in English too, but then he will switch back to Indonesian. In children's daily life, these kinds of switching can happen to everybody, like parents, teachers, or the children themselves. At the classroom, it also happens a lot in teacher while explaining or asking question to the students. There are positive and negative effects if teachers conduct code switching to the students. The advantages are that the teaching and learning process becomes smoother. It will also be succeed because teacher can balance students' language ability, so they can comprehend the lesson material faster. Instead, code switching will ruin the Indonesian order. As a result, the learning process will be less formal [25]. Children will also imitate their teacher to switch language because they think it is okay to do. If teachers do not guide and explain the rules in using code switching, it will be a habit and they cannot differentiate when they should and should not using that. 


\section{Conclusion}

There are people who believe that being a bilingual brings disadvantages in children's language development. However, it is concluded to be wrong. Bilinguals' cognitive skills development is proven better than monolinguals. They can distinguish sounds, encode and decode different language systems, understand different grammars, be sensitive in choosing words, master a lot of receptive vocabulary, separate information to be more focus in the important one. However, they also face challenges to switch and mix languages easily in their sentences. This can happen inside or outside the sentences, in the form of words, phrases, idioms, fillers, tags, interjections, and even another sentence. Sometimes, this results a good impact, but it will also ruin their language grammar because they are not able to use one proper language system only.

\section{References}

[1] Taeschner, T. The sun is feminine: A study on language acquisition in bilingual children. Vol. 13. Springer Science \& Business Media, Germany (2012).

[2] Bishop, D., \& Mogford, K. (Eds). Language development in exceptional circumstances. Psychology Press, UK (2013).

[3] Saville-Troike, M., \& Barto, K. Introducing second language acquisition. Cambridge University Press, UK (2016).

[4] Ellis, R. Second language acquisition. Oxford University Press, UK (2003).

[5] Bialystok, E., Craik, F.I.M., \& Luk, G. Bilingualism: Consequences for mind and brain. Vol. 16, pp. 240-250. Trends in Cognitive Science (2012).

[6] Zed, M. Metode Penelitian Kepustakaan. Yayasan Obor Indonesia, Indonesia (2004).

[7] Hoff, E. Language development in bilingual children. The Cambridge handbook of Child Language. Cambridge University Press, UK (2015).

[8] Meisel, J.M. (Ed.). Two first languages: Early grammatical development in bilingual children. Vol. 10. Walter de Gruyter, Germany (2010).

[9] De Houwer, A. Bilingual language acquisition. The Handbook of Child Language (eds P. Fletcher and B. MacWhinney). Blackwell Publishing Ltd., US (2020).

[10] Appel, R., \& Muysken, P. Language contact and bilingualism. Amsterdam University Press, Netherland (2006).

[11] Bialystok, E., Luk, G., Peets, K.F., \& Yang, S. Receptive vocabulary differences in monolingual and bilingual children. Vol. 13, pp. 525-531. Bilingualism: Language and Cognition (2009).

[12] Scheele A.F., Leseman, P.P.M., \& Mayo, A.Y. The home language environment of monolingual and bilingual children and their language proficiency. Vol. 31, pp. 117140. Applied Psycholinguistics (2010).

[13] Blom, E., Boerma, T., Bosma, E., Cornips, L., \& Everaert, E. Cognitive advantages of bilingual children in different sociolinguistic contexts. Vol. 8, pp. 1-12. Frontiers in Psychology (2017).

[14] Morales, J., Calvo, A., \& Bialystock, E. Working memory development in monolingual and bilingual children. Vol. 114, pp. 187-202. Journal of Experimental Child Psychology (2013).

[15] Kapa, L. L., \& Colombo, J. Attentional control in early and later bilingual children. Vol. 28, pp. 233-246. Cognitive development (2013). 
[16] Poeste, M., Müller, N., \& Gil, L.A. Code-mixing and language dominance: Bilingual, trilingual and multilingual children compared. Vol. 16, pp. 459-491. International Journal of Multilingualism, (2019).

[17] Grosjean, F. Bilingualism: A short introduction. Vol. 2. The Psycholinguistics of Bilingualism (2013).

[18] Gardner-Chloros, P. Code-switching. Cambridge University Press, UK (2009).

[19] Hoffmann, C. An introduction to bilingualism. Routledge, US (2014).

[20] Sanubari, C.E.: A case of code switching in Childrens School. Vol. 31, pp. 84-86. ESSAY: Research Article Journal (2016).

[21] Yletyinen, H. The functions of codeswitching in EFL classroom discourse. Tesis University of Jyväskylä, Findland (2004).

[22] Muharam, R. Alih kode, campur kode, dan interferensi yang terjadi dalam pembicaraan bahasa Indonesia dan bahasa Melayu Ternate. Edisi Khusus. Pp. 197-207. (2011).

[23] Poplack, S. Sometimes I'll start a sentence in Spanish y termino en español: Toward a typology of code-switching. Vol. 18, pp. 221-256 The Bilingualism Reader (2000).

[24] Papalia, D.E., Olds, S.W., \& Feldman, R.D. Human development (Ninth Edition). McGraw-Hill Companies, US (2004).

[25] Aryani, N. Alih kode dan campur kode guru-siswa dalam pembelajaran tematik kelas V Sekolah Dasar Negeri 05 Indralaya Kabupaten Ogan Ilir. Vol. 10, pp. 25-33. Jurnal Pembahsi (Pembelajaran Bahasa dan Sastra Indonesia) (2020). 